the direction of motion is all that can be tolerated. On the other hand, if there is no angular error, and the orbit is to be within the same limits, the velocity error must be no more than $\pm 450 \mathrm{ft}$. $/ \mathrm{sec}$. No official commitment on expected accuracy is forthcoming, though it was suggested in discussion that as many as fifty satellites might have to be launched to give a reasonable likelihood that one might be placed in a satisfactory orbit. Precisely what would form a 'satisfactory' orbit, is, in any event, difficult to define. The magnitude of the air density - and so of the drag-at such extreme altitudes is the chief factor governing the useful life-time of the vehicle, but is also one of the unknown properties which it is hoped that observation of the satellite may enable to be evaluated. Tentative estimates put the mean loss in apogee and perigee at (initially) about $250 \mathrm{ft}$. and $200 \mathrm{ft}$. per day, respectively. Because of the Earth's oblateness, the variation in the radius of the apogee and perigee is in fact oscillatory, with a period of forty days and an amplitude of about two miles.

It is hoped that observation of the track of the satellite vehicles may also supply data leading to determinations of the variation of gravitational acceleration, and of the shape of the Earth. In addition, it is hoped to be able to interlock the geodetic networks of the continents more closely than has been possible before. During the initial circuits in the orbit, the satellite can be located by the radio signals it sends out; but as the batteries have only a limited life, later observation will depend on visual and photographic records, when the satellite is visible before dawn or after sunset. In this 'Operation Moonwatch', the help of amateur astronomers all over the world is being enlisted, through the International Astronautical Federation. The track of the satellites takes them eastwards as far south as $45^{\circ}$ latitude on the Greenwich meridian, and north to the same latitude at a longitude of $180^{\circ}$ (so that they will not be visible in Britain). Some other data are to be telemetered from the satellites, though it seems that there is little room for the installation of many instruments. The weight of the satellite is only $21 \frac{1}{2} \mathrm{lb}$. (The complete take-off weight of the three stages is $22,600 \mathrm{lb}$., implying a mass ratio of more than a thousand.) The nature of the observations to be made was not announced, though the possibilities are without limit. High on the list of priorities is the counting of impacts by meteors. This and many other experimental techniques which might be involved are being practised already, and several of the papers presented at the Congress dealt with them.

One of the greatest of the potential hazards to man in space flight is the effect of heavy primary cosmic radiation. More than twenty-five stratosphere balloon flights conducted by the United States Air Force have carried biological specimens to altitudes above $30 \mathrm{~km}$. in geomagnetic latitudes above $55^{\circ}$. Although no somatic health hazard has been observed cver periods of about twenty-four hours-the longest period of exposure obtained-the repeated observation of streaks of grey hair on black mice, 200 in width, has suggested that a so far unidentified mechanism causes wider radial spread of radiation effects (by some 20 times) than has been predicted before. In another paper, details were reported of personal experiences during half-minute periods in a zero-gravity condition. (These were experiments conducted in an aircraft.) The majority of the subjects tested reported as feeling "very comfortable".

Looking still further ahead, another paper discussed the time dilation effect of relativity theory, and its effect on humans travelling in a vehicle moving at speeds near that of light. The general conclusion seemed to be that man's life-time would be effectively increased to such an extent that he can survive outward journeys which in terms of lightyears of distance far exceed his normal life-time.

T. NONWEILER

\title{
OBITUARIES
}

\section{Prof. J. B. Leathes, F.R.S.}

WITr the death, at Montreux on September 14 at the age of ninety-two, of Prof. John Beresford Leathes, physiology lost another of its dwindling links with the past century. Born on November 5, 1864, the son of a clergyman, and educated at Winchester and New College, Oxford, he also was intended for the Church; but a natural bent for science drew him to the study of medicine, and he qualified M.B. in 1893, and F.R.C.S. a year later, from Guy's Hospital, London.

A talent for chemistry, the teaching of which was a strong feature at Guy's, decided Leathes to follow the applications of chemical knowledge to the elucidation of physiological problems, in pursuit of which plan ho went to work for two years with Drechsel at Berne, and then under Schmiedeberg in Strasbourg. On his return, like Sherrington before him, he was appointed to the lectureship in physiology at St. Thomas's Hospital, where he stayed for some ten years, during the last eight of which he also held a part-time appointment at the Lister Institute, which was one of the main foci of development for the rapidly evolving subject of biochemistry. $\mathrm{He}$ thus became one of that small and devoted band which included C. J. Martin, Harden and Young, Cathcart, Dakin and Raper, who did so much to forward the interests of that subject in its formative years. It was in that stimulating environment that his interest in metabolic problems was aroused, and where his book, "Problems in Animal Metabolism", was produced. His first published papers dealt with body fluids, proteolytic enzymes, protein metabolism, and the fat content of various muscles. Most of his subsequent work had to do with fat metabolism, and in much of this he had the collaboration of H. S. Raper ; their joint monograph on "The Fats" (1910 and 1925) is still a standard work.

In 1909 he became professor of pathological chemistry at Toronto, where he was shortly joined by Raper. During these years he was elected to the fellowship of the Royal Society (1911). In 1915 he went as professor of physiology to Sheffield, in succession to J. S. Macdonald, who had moved to Liverpool, and he remained there until his retirement in 1933. 
Leathes took a keen and practical interest in medical and dental education, and by reason of his work on the General Medical Council, and as dean for nine years of the Sheffield Medical School, he not only influenced his own University, but also played an important part in shaping the medical curriculum of his time. It is no more than fair to say that he, and the late Sir Arthur Hall, together were largely responsible for making the Sheffield Medical School the outstanding success it became. Their aim was to unify the medical curriculum; and they did this by weakening the barriers between the pre-clinical and clinical courses of study by extending physiology and biochemistry, with appropriate laboratories, into the ward teaching of clinical medicine-a development which has since been applied in other schools. The results of the experiment were encouraging, as also were those of an innovation which Leathes introduced into the B.Sc. course, and which consisted in making the candidates spend a further year after the final examination working up some special field, on which they produced a thesis, which had to be approved before the degree was granted. The average standard of these theses was surprisingly good, and the subject, in some instances, provided the new graduate with 8 field into which he could enter with some confidence for further study.

Leathes was elected to the Physiological Society in 1895 , and in 1952 was accorded the distinction of honorary membership. He served for three periods on its committee, and for ten years as an editor of the Journal of Physiology. This latter service, often now forgotten, was perhaps his best contribution to British physiology, for he took infinite and unsparing pains in helping authors, young and old, who lacked the ability to express themselves clearly. As he was in Toronto when the Biochemical Society was formed in 1911, he happened not to have been an original member, but he joined it in 1913.

In 1921 he was elected a fellow of the Royal College of Physicians, and gave the Croonian Lecture in 1923 ; it dealt with fat metabolism in various aspects, and in its relation to cellular structure and functions. He also gave the Harveian Oration in 1930, on "The Birth of Chemical Biology". Other honours included the D.Sc. Sheffield in 1933, and Manchester 1936, and the honorary fellowship of New College, Oxford.

Leathes was essentially a modest and scholarly man, of kindly and phlegmatic disposition, one of the few physiologists with a classical education, and a good linguist; he began the study of Russian at the age of eighty. Tall and wiry, he was, even at that age, good for a brisk walk of ten miles or more. Among other accomplishments, he was a pastellist of discernment, despite his high degree of myopia, or perhaps even on account of it, as he was unaware of much landscape detail which tends to distract the amateur. After his retirement he moved to Wantage, and worked in the Physiological Laboratory at Oxford, with John Mellanby. Their published work, which was interrupted by the Second World War, dealt with thrombokinase, and with the action of lecithin upon it. He then moved successively to Lyme Regis, London, Southbourne, and finally to Switzerland, near the scene of some of his happier early years.

Leathes spent his life largely in helping others by patient and unselfish acceptance of responsibilities which brought no ponderable reward-service on the Counsil of the Royal Society, 1924-26, on the Medical Research Council, 1928-31, the General Medical Council, 1919-38, and on its Education Committee, of which he was chairman in 1931. But he will long be remembered with affection by many friends and pupils. C. Lovati Evans

\section{Dr. A. E. J. Vickers}

DR. A. E. J. VICkERs, who died suddenly on September 8 at the age of fifty-eight, was director of research at the Thermal Syndicate, Itd., Wallsend, Northumberland, a position he had held since November 1947; he was elected to the Board of Directors in April 1953. His early academic education began with training in 1915 in Sheffield for the teaching profession; but, probably influenced by war work in a munitions factory, he decided to make chemistry his future profession and, following study in Stoke and London, took an external London B.Sc. in chemistry in 1922 .

He then joined the late Dr. J. W. Mellor, of the British Refractories Research Association (now the British Ceramic Research Association), Stoke-onTrent, where he developed an interest in mineralogy, and in 1927 he took the post of chief chemist to Buxton Lime Firms Co., Ltd. (now the Lime Division of Imperial Chemical Industries, Ltd.). Two years later Dr. Vickers moved to the Billingham works of Imperial Chemical Industries, Ltd., and continued investigations in the problems of refractories and in mineralogy, gaining his Ph.D. in 1935 with a thesis on the colloidal properties of clay. During the latter part of his stay at Billingham he was in charge of research on ceramics, mineralogy and physical methods, including a variety of applications of spectroscopy and microscopy, and when he moved in 1947 to the Thermal Syndicate, Ltd., his work ccntinued to be largely in the field of ceramics, but at higher temperatures than heretofore.

Dr. Vickers was keenly interested in the work of scientific and technical societies, including the Royal Institute of Chemistry, the Society of Glass Technology and the Society of Chemical Industry, and he was a founder member of the Institute of Ceramics. He was also very much concerned with higher education, being a member of the council of St. John's College in the University of Durham. Apart from his professional work, Dr. Vickers was a keen photographer, gardener and musician, and he was an active member of the Anglican Church. $\mathrm{He}$ is survived by his wife and by a son and a daughter, training respectively for the medical and dental professions.

\section{Prof. B. M. Duggar}

Benjamin Minge Duggar, botanist, mycologist, plant physiologist, plant pathologist and microbiologist, who died at New Haven, Connecticut, in mid-September, a fortnight after his eighty-fourth birthday, had a long and varied career. After holding posts in his native state of Alabama and elsewhere, Duggar became professor of botany in the University of Missouri in 1902. Afterwards he was professor of plant physiology first at Cornell (1907-12) and then in the University of Washington (1912-27), from where he moved to the University of Wisconsin as professor of plant physiology, plant pathology and economic botany (1927-43). Finally, in 1944, he became consultant on mycological research and production to the Lederle Laboratories Division of the American Cyanamid Co. 